\title{
HUBUNGAN MOTIVASI PERAWAT DENGAN TINGKAT KEPATUHAN MELAKUKAN CUCI TANGAN
}

\section{THE CORELATION BETWEEN NURSE MOTIVATION AND THE COMPLIANCE LEVEL AT HAND WASHING}

\author{
Fakhrudin Nasrul Sani ${ }^{1)}$, Muthiah Rissa Pratiwi ${ }^{2)}$ \\ ${ }^{1}$ D3 Keperawatan, STIKes Kusuma Husada Surakarta \\ email: fakhrudin_ns@ymail.com \\ ${ }^{2}$ D3 Keperawatan, STIKes Kusuma Husada Surakarta \\ email: msicha27@gmail.com
}

\begin{abstract}
Abstrak
Salah satu strategi keselamatan pasien adalah pengurangan risiko berbagai infeksi dengan cara mencuci tangan. Cuci tangan dilakukan dengan prosedur yang benar yaitu 6 teknik secara berurutan pada waktu/momen yang tepat.Tingkat kepatuhan mencuci tangan perawat dipengaruhi oleh beberapa faktor, diantaranya adalah motivasi. Penelitian ini bertujuan untuk mengetahui apakah ada hubungan motivasi perawat rawat inap dengan tingkat kepatuhan dalam melakukan 6 langkah cuci tangan yang benar di RSI Klaten. Desain penelitian ini adalah deskriptif korelatif dengan pendekatan cross sectional. Pengumpulan data dilakukan dengan kuesioner untuk mengetahui motivasi perawat dan lembar observasi untuk mengetahui kepatuhan cuci tangan perawat dengan sampel 61 orang perawat. Hasil penelitian sebagian besar perawat rawat inap di RSI Klaten memiliki motivasi 6 langkah cuci tangan dengan benar dengan katagori lemah (52,5\%), sedangkan tingkat kepatuhan cuci tangan sebagian besar tidak patuh $(57,4 \%)$. Hasil uji chi square didapatkan ada hubungan motivasi perawat rawat inap dengan tingkat kepatuhan dalam melakukan 6 langkah cuci tangan yang benar di RSI Klaten $(p=0,000<0,05)$. Disarankan kepada perawat hendaknya membiasakan prosedur 6 langkah cuci tangan yang benar untuk mencegah terjadinya infeksi dari berbagai penyakit.
\end{abstract}

Kata Kunci: Motivasi, tingkat kepatuhan, cuci tangan.

\begin{abstract}
One of the patient safety strategies is to reduce the risk of various infections by washing hands. Wash your hands with the correct procedure that is 6 techniques in sequence at the right time I moment. The level of compliance hand washing of nurses is influenced by several factors, such as motivation. This study aims to determine whether there is a corelation between nurses motivation with the level of compliance in doing 6 steps of hand washing properly in RSI Klaten. The design of this research was descriptive correlative with cross sectional approach. The data was collected by questionnaire to know the nurse motivation and observation sheet to know the compliance of nurse hand washing with samples of 61 nurses. The results obtained of most of the inpatient nurses at RSI Klaten were motivated by 6 steps of handwashing properly with the weak category (52.5\%), while the hand washing compliance level was largely disobedient (57.4\%). The result of ujichi square showed that there was a correlation between in-patient nurse motivation and complained level in performing 6 handwashing steps properly in RSI Klaten $(p=0,000<0,05)$. It is recommended that nurses should familiarize the correct 6-step handwashing procedure to prevent infection from various diseases.
\end{abstract}

Keywords: Motivation, compliance level, handwashing. 


\section{PENDAHULUAN}

Rumah sakit sebagai fasilitas pelayanan kesehatan mempunyai peran sangat penting dalam meningkatkan derajat kesehatan masyarakat. Oleh karena itu rumah sakit dituntut memberikan perlayanan yang bermutu, efektif dan efisien untuk menjamin patient safety sesuai dengan standar yang telah ditentukan. Salah satu indikator patient safety adalah pengurangan resiko infeksi terkait pelayanan kesehatan (WHO, 2012).

Infeksi atau yang sekarang disebut sebagai infeksi yang berhubungan dengan pelayanan kesehatan atau Health-care Associated Infection (HAIs) merupakan masalah penting diseluruh dunia yang meningkat (Depkes RI, 2012). Tingkat infeksi yang terjadi di beberapa negara Eropa dan Amerika masih sangat rendah yaitu sekitar 19\% dibandingkan dengan kejadian di negara-negara Asia, Amerika Latin, Afrika yang tinggi hingga mencapai lebih dari $40 \%$ dan menurut WHO, angka kejadian infeksi di RS di negara-negara Asia sekitar 3-21\% (rata-rata 9\%) (Depkes, 2012.)

Rata- rata kejadian infeksi nosokomial Indonesia sekitar 9,1\% dengan variasi 6,1\%-16,0\%. Penelitian yang pernah dilakukan di 11 rumah sakit di DKI Jakarta pada 2004 menunjukkan bahwa 9,8\% pasien rawat inap mendapat infeksi nosokomial selama dirawat. Angka kejadian infeksi nosokomial RSUP Dr. Sardjito Yogyakarta tahun 2005 sebesar 7,95 \%, dan kejadian infeksi nosokomial RSUP Dr.Wahidin Sudirohusodo pada trimester III tahun 2009 sebesar 4,4 $\%$. Data dari panitia pengendali infeksi nosokomial RSI Klaten diperoleh kejadian infeksi nosokomial pada tahun 2012 masih termasuk tinggi yaitu sekitar $15 \%$ (Survey PPI RSI Klaten, 2012).

Undang-undang Nomor 4 tahun 2009 tentang rumah sakit, menyatakan bahwa "setiap pasien mempunyai hak memperoleh keamanan dan keselamatan dirinya selama dalam perawatan di Rumah Sakit”. Salah satu poinya yaitu menghindari adanya resiko infeksi nosokomial di rumah sakit, dan mencegah terjadinya kerugian pada pasien yang diakibatkan kesalahan dari petugas medis, paramedis, atau non medis (Dep Kes, 2013). Salah satu cara untuk mengurangi infeksi nosokomial yaitu dengan cuci tangan.

Menurut pendapat Perry \& Potter (2005), mencuci tangan salah satu kewajiban dari tenaga kesehatan yaitu dengan mencuci tangan merupa- kan teknik dasar yang paling penting dalam pencegahan dan pengontrolan infeksi nosokomial. Perawat dapat memperhatikan apakah mereka sudah melakukan prosedur cuci tangan yang baik dan benar, karena perawat adalah petugas kesehatan yang paling rentan menjadi perantara terjadi infeksi (Nita,dkk 2012).

Cuci tangan menjadi salah satu langkah yang efektif untuk memutuskan rantai transmisi infeksi, sehingga insidensi nosokomial dapat berkurang. Pencegahan dan pengendalian infeksi mutlak harus dilakukan oleh perawat, dokter, dan seluruh orang yang terlibat dalam perawatan pasien. Salah satu komponen standar kewaspadaan dan usaha menurunkan infeksi nosokomial adalah menggunakan panduan kebersihan tangan yang benar dan mengimplementasikan secara efektif (Joko, 2012). Praktek cuci tangan oleh perawat yang direkomendasikan adalah lima moment yaitu sebelum kontak dengan pasien, sebelum melakukan tindakan aseptik, setelah kontak dengan pasien, setelah kontak dengan cairan tubuh pasien, setelah kontak dengan peralatan lingkungan sekitar pasien.

Cuci tangan yang benar adalah cuci tangan yang telah dilaksanakan dengan prosedur yang benar dengan langkah-langkah enam langkah yang secara berurutan. Tujuan dilakukannya cuci tangan adalah mengangkat mikroorganisme yang ada di tangan, mencegah infeksi silang (cross infection), menjaga kondisi steril, melindungi diri dan pasien dari infeksi, memberikan perasaan segar dan bersih. Kepatuhan cuci tangan perawat khususya di RSI klaten sangat perlu diperhatikan agar tetap dilaksanakan dengan prosedur 6 langkah cuci tangan yang tepat. Pelaksanaan cuci tangan yang baik dan benar perlu dilakukan dengan keinginan dari perawat itu sendiri yang sering disebut motivasi. Motivasi yang dimiliki dapat meningkatkan kepatuhan dalam melaksanakan 6 langkah cuci tangan yang baik dan benar. Motivasi adalah suatu dorongan atau keinginan dalam diri manusia yang menyebabkan individu melakukan sesuatu untuk memenuhi kebutuhannya.

Menurut Hamzah (2013) menyimpulkan dari beberapa psikolog menyebutkan motivasi sebagai konstruk hipotesis yang digunakan untuk menjelaskan keinginan, arah intensitas, dan keajegan perilaku yang diarahkan oleh tujuan. Motivasi merupakan proses psikologis yang dapat menjelaskan perilaku seseorang. Perilaku hakikatnya merupakan orientasi pada satu tujuan, dengan 
kata lain perilaku seseorang dirancang untuk mencapai tujuan. (dikutip dari Rolly, 2015).

Berdasarkan studi pendahuluan yang dilakukan oleh peneliti yang dilakukan di ruang perawatan RSI klaten melalui teknik wawancara dan observasi didapatkan motivasi perawat untuk cuci tangan lima moment sudah bagus, meliputi: perawat melakukan cuci tangan sebelum dan setelah kontak dengan pasien, cairan tubuh pasien, lingkungan sekitar pasien, sebelum melakukan tindakan aseptik. Sedangkan untuk motivasi perawat dalam melakukan cuci tangan 6 langkah yang benar masih kurang hal ini disebabkan karena perawat merasa terlalu rumit, merasa kurang bersih saat cuci tangan, merasa takut kalau ada sidak dari petugas PPI.

RSI Klaten telah mebuat prosedur tetap cuci tangan yang benar, menyediakan sarana cuci tangan berupa wastafel yang dilengkapi sabun antimikroba maupun dengan teknik handrub, dan pengetahuan tentang prosedur cuci tangan yang benar semakin diperbaiki dan ditingkatkan melalui studi dan kerjasama dengan berbagai pihak. Berdasarkan hasil pengamatan awal peneliti di ruang arofah Rumah Sakit Islam Klaten pada perawat yang jaga dan banyak intensitas melakukan perawatan pada pasien didapatkan kurangya kepatuhan perawat untuk melakukan cuci tangan enam langkah yang benar. Padahal diruang tersebut untuk fasilitas gambar enam langkah dan prosedur cuci tangan sudah tersedia dengan baik. Untuk sosialisasi yang diberikan dari petugas PPI tentang 6 langkah cuci tangan dilakukan terakhir bulan February 2015 untuk menghadapi Re-Surve Akreditasi dari KARS.

Berdasarkan pengamatan data surveilans dan standar kewaspadaan komite PPI RSI Klaten pada bulan Januari 2016 untuk kepatuhan kebersihan 6 langkah cuci tangan dokter $28 \%$, perawat $39 \%$, laboratorium 20\%. Sedangkan untuk kepatuhan kebersihan tangan (Five Moment) dokter $85,9 \%$, perawat $90,4 \%$, laboratorium $88,7 \%$. Hasil wawancara dari petugas surveilans PPI didapatkan kurang lebih 170 perawat yang belum melakukan cuci tangan sesuai prosedur yang ditetapkan RS. Berdasarkan fenomena tersebut peneliti tertarik untuk meneliti tentang "Hubungan antara motivasi perawat rawat inap dengan tingkat kepatuhan dalam melakukan 6 langkah cuci tangan yang benar di Rumah Sakit Islam Klaten".

\section{METODE PENELITIAN}

Penelitian ini merupakan penelitian kuantitatif dengan metode observasi analitik yaitu untuk mencari hubungan antara variabel bebas dengan variabel terikat yang analisisnya untuk menentukan ada tidaknya hubungan antara variabel sehingga perlu disusun hipotesisnya, dengan pendekatan subjek cross sectional dimana peneliti menekankan waktu pengukuran/observasi data variabel independen dan variabel dependen hanya satu kali satu saat. Penilitian ini dilakukan di RSI Klaten, pada bulan Juli 2016. Sampel dalam penelitian ini sebanyak 61 responden, Teknik pengambilan sampel menggunakan Purposive Sampling. Kriteria inklusi yang digunakan dalam penelitian ini sebagai berikut: perawat pelaksana asuhan keperawatan, perawat yang bertugas di ruang rawat inap, minimal masa kerja 1 tahun, dan bersedia menjadi responden penelitian

Kriteria eksklusif yang digunakan dalam penelitian ini sebagai berikut: perawat yang bekerja dibagian administrasi, Perawat di ruang Khusus, dan perawat yang mengalami luka ditangan sehingga tidak bisa melakukan tindakan keperawatan.

Instrumen penelitian ini adalah kuesioner dan observasi. Kuesioner adalah jenis pengukuran dengan mengumpulkan data secara formal kepada subjek untuk menjawab pertanyaan secara tertulis (Nursalam 2011). Kuesioner dalam penelitian ini dibuat sendiri berupa pertanyaan yang digunakan untuk mengumpulkan data dari responden mengenai motivasi perawat untuk melakukan 6 langkah cuci tangan yang benar. Skala pengukuran kuesioner dengan menggunakan skala Likert sebanyak 25 pertanyaan. Dengan pertanyaan 13 favorable, penilaianya $\mathrm{SS}=$ sangat setuju (4), S = setuju (3), TS = tidak setuju (2), STS = sangat tidak setuju (1)dan pertanyaan 12 unfavorable, penilaianyaSS = sangat setuju (1), $S$ = setuju (2), TS = Tidak setuju (3), STS = Sangat tidak setuju (4).

Peneliti juga menggunakan lembar observasi kepatuhan 6 langkah cuci tangan yang benar. Penilaian kepatuhan 6 langkah cuci tangan yang benar adalah:

1. Patuh jika 6 langkah cuci tangan dilakukan.

2. Tidak patuh jika salah satu dari 6 langkah cuci tangan tidak dilakukan. 
Analisa data dilakukan untuk menjawab hipotesis penelitian. Untuk alasan tersebut dipergunakan uji statistik yang cocok dengan variabel penelitian (Notoatmodjo, 2005). Analisa data terdiri dari:

\section{Analisa univariat}

Analisa univariat yaitu analisa yang dilakukan terhadap tiap variabel dari hasil penelitian yaitu karakteristik respondent, motivasi perawat, kepatuhan perawat dalam melakukan 6 langkah cuci tangan yang benar.

\section{Analisa bivariat}

Analisa bivariat adalah analisis yang dilakukan terhadap dua variabel yang diduga berhubungan atau berkorelasi (Sugiyono, 2014). Analisa bivariat pada penelitian ini yaitu dengan menggunakan Chi-square $\left(\mathrm{x}^{2}\right)$ adalah teknik statistik yang digunakan untuk menguji hipotesis bila dalam populasi terdiri atas dua atau lebih klas dimana data berbentuk nominal dan sampelya besar, untuk melihat hubungan antara variabel bebas dengan variabel terikat, uji statistik yang digunakan adalah penghitungan Chi-square test. Pengambilan keputusan hasil didasarkan pada batas kemaknaan 0,05 . Jika p value $\alpha 0,05$ maka hasil yang diperoleh bermakna secara statistik, dan jika nilai $\mathrm{p}$ value $\alpha \quad 0,05$ maka hasil penghitungan tidak bermakna secara stastistik.

\section{HASIL DAN PEMBAHASAN}

Karakteristik responden dalam penelitian ini adalah berdasarkan umurdan jenis kelamin.

Tabel 1. Distribusi Frekuensi Responden Berdasarkan Umur ( $\mathrm{n}=61)$

\begin{tabular}{ccc}
\hline Umur & Frekuensi & Prosentase \\
\hline $20-30$ & 26 & 42,6 \\
\hline $31-40$ & 27 & 44,3 \\
\hline $41-50$ & 7 & 11,5 \\
\hline $51-60$ & 1 & 1,7 \\
\hline Jumlah & 61 & 100 \\
\hline
\end{tabular}

Berdasarkan tabel 1 menunjukkan bahwa umur responden terbanyak adalah pada rentang 31- 40 tahun. Hal tersebut menunjukkan perawat dirawat inap tempat penelitian sebagian besar adalah tenaga pada usia produktif dan masih jauh dari masa pensiun.
Tabel 2. Distribusi Frekuensi Responden Berdasarkan Jenis Kelamin

\begin{tabular}{ccc}
\hline Jenis Kelamin & Frekuensi & Prosentase \\
\hline Laki-laki & 21 & 41,2 \\
\hline Perempuan & 40 & 58,8 \\
\hline Jumlah & 61 & 100 \\
\hline
\end{tabular}

Berdasarkan tabel 2 menunjukkan bahwa jenis kelamin responden sebagian besar adalah perempuan.

Tabel 3. Distribusi Frekuensi Responden Berdasarkan Tingkat Pendidikan

\begin{tabular}{ccc}
\hline $\begin{array}{c}\text { Tingkat } \\
\text { Pendidikan }\end{array}$ & Frekuensi & Prosentase \\
\hline D3 & 61 & 100 \\
\hline Jumlah & 61 & 100 \\
\hline
\end{tabular}

Berdasarkan tabel 3 menunjukkan bahwa tingkat pendidikan perawat kesemuanya berpendidikan D3 yaitu sebanyak 61 responden $(100 \%)$.

Tabel 4. Distribusi Frekuensi Motivasi Perawat Rawat Inap dalam Melakukan 6 Langkah Cuci Tangan yang Benar di Rumah Sakit Islam Klaten Tahun 2016

\begin{tabular}{lcc}
\hline \multicolumn{1}{c}{ Motivasi } & Frekuensi & Prosentase \\
\hline Kuat & 16 & 26,2 \\
\hline Sedang & 13 & 21,3 \\
\hline Lemah & 32 & 52,5 \\
\hline Jumlah & 61 & 100 \\
\hline
\end{tabular}

Berdasarkan tabel 4 diketahui bahwa sebagian besar responden memiliki motivasi lemah dalam melakukan 6 langkah cuci tangan yang benar yaitu dengan kategori motivasi sedang atau 13 responden $(21,3 \%)$.

Tabel 5. Kepatuhan Cuci Tangan Perawat Rawat Inap dalam Melakukan 6 Langkah Cuci Tangan yang Benar di Rumah Sakit Islam Klaten Tahun 2016

\begin{tabular}{lcc}
\hline \multicolumn{1}{c}{ Motivasi } & Frekuensi & Prosentase \\
\hline Patuh & 26 & 42,6 \\
\hline Tidak Patuh & 35 & 57,4 \\
\hline Jumlah & 61 & 100 \\
\hline
\end{tabular}


Berdasarkan tabel 5 diketahui bahwa sebagian besar responden memiliki kepatuhan dalam melakukan 6 langkah cuci tangan yang benar yaitu dengan kategori tidak patuh $57,4 \%$.

Pengujian hipotesis dilakukan dengan dengan menggunakan uji Chi-square $\left(X^{2}\right)$. Uji Chi-square merupakan teknik analisis statistik yang digunakan untuk menguji hipotesis bila dalam populasi terdiri atas dua atau lebih kelas dimana data berbentuk nominal dan sampelnya besar, untuk melihat hubungan antara variabel bebas dengan variabel terikat, uji sttaistik yang digunakan adalah uji Chi-square. Pengambilan keputusan hasil berdasarkan pada batas kemaknaan 0,05. Jika $\mathrm{p}$ value $<0,05$ maka yang diperoleh kemaknaan secara statistik, dan jika nilai $\mathrm{p}$ value $>0,05$ maka hasil perhitungan tidak bermakna secara statistik.

Adapun hasil analisis bivariat tentang hubungan motivasi perawat rawat inap dengan tingkat kepatuhan daam melakukan 6 langkah cuci tangan yang benar di RSI Klaten dapat dilihat pada tabel dibawah ini.

Tabel 6. Hubungan Motivasi Perawat Rawat Inap dengan Tingkat Kepatuhan dalam Melakukan

6 Langkah Cuci Tangan yang Benar di RSI Klaten

\begin{tabular}{lccccccc}
\hline Motivasi & Patuh & \multicolumn{7}{c}{$\begin{array}{c}\text { Kepatuhan } \\
\text { Tidak } \\
\text { Perawat }\end{array}$} & & \multicolumn{1}{c}{ Jumlah } & & $\boldsymbol{P}$ \\
& $\mathbf{N}$ & $\mathbf{\%}$ & $\mathbf{N}$ & $\boldsymbol{\%}$ & $\mathbf{n}$ & $\boldsymbol{\%}$ & \\
\hline Lemah & 4 & 6,5 & 28 & 45,9 & 20 & 52,4 & 0,000 \\
Sedang & 9 & 14,8 & 4 & 6,5 & 25 & 21,3 & \\
Kuat & 13 & 21,3 & 3 & 5 & 16 & 26,3 & \\
\hline Jml & & & & & 61 & 100 & \\
\hline
\end{tabular}

$P=$ probabilitas dengan uji chi square

Berdasarkan tabel 6 terlihat bahwa responden yang memiliki motivasi yang kuat dalam melakukan 6 langkah cuci tangan yang benar dan patuh yaitu sebanyak 13 responden atau sebesar $21,3 \%$, dan responden yang memiliki motivasi yang kuat dalam melakukan 6 langkah cuci tangan yang benar tetapi mereka tidak patuh yaitu sebanyak 3 responden atau sebesar 5\%.

Responden yang memiliki motivasi sedang dalam melakukan enam langkah cuci tangan yang benar dan mereka patuh sebanyak 9 responden atau sebesar $14,8 \%$, dan responden yang memiliki motivasi sedang dalam melakukan enam langkah cuci tangan yang benar dan mereka tidak patuh sebanyak 4 responden atau sebesar
6,5\%. Responden yang memiliki motivasi yang lemah dalam melakukan enam langkah cuci tangan yang benar dan dia patuh sebanyak4 responden atau sebesar 6,5\%, serta untuk responden yang memiliki motivasi yang lemah dalam melakukan enam langkah cuci tangan yang benar dan dia tidak patuh sebanyak 28 responden atau sebesar 45,9\%.

Berdasarkan hasil analisis tabel 4.6 diatas kemudian diperoleh nilaip.Value 0.000 jika di bandingkan dengan $\alpha=0,05$ maka Pearson ChiSquare $\leq 0,05$, hal ini berarti ada hubungan antara motivasi perawat rawat inap dengan tingkat kepatuhan dalam melakukan 6 langkah cuci tangan yang benar di RSI Klaten. Untuk lebih jelasnya dapat dilihat pada tabel 8 di bawah ini.

Tabel 7. Hasil Analisis Chi Square

Chi-Square Tests

\begin{tabular}{lrrr}
\hline & Value & Df & $\begin{array}{c}\text { Asymp. } \\
\text { Sig. (2- } \\
\text { sided) }\end{array}$ \\
\hline Pearson Chi- & $25,398^{\mathrm{a}}$ & 2 &, 000 \\
Square & & & \\
Likelihood Ratio & 27,627 & 2 &, 000 \\
Linear-by-Linear & 22,979 & 1 &, 000 \\
N of Valid Cases & 61 & & \\
\hline
\end{tabular}

a. 0 cells $(0,0 \%)$ have expected count less than

5 . The minimum expected count is 6,82 .

\section{Usia}

Jumlah responden penelitian diketahui bahwa mayoritas responden berumur 31-40 tahun sebanyak 27 responden (44,3\%).Berdasarkan pendapat peneliti bahwa seperti kondisi ditempat penelitian memang sebagian besar dari responden ialah mereka yang masih berumur dewasa awal, dimana mereka masih memiliki fisik yang kuat, semangat yang cukup tinggi dan juga kemampuan daya ingat dan daya serat ketika diberi ilmu atau ketrampilan baru, mereka lebih mudah menguasai dari pada responden yang berusia tua. Hal ini sejalan dengan teori yang telah dikemukakan bahwa faktor internal yang mempengaruhi motivasi diantaranya adalah kematangan pribadi/ umur seseorang. Orang bersifat egois dan kemanja-manjaan biasanya akan kurang peka dalam menerima motivasi yang diberikan sehingga agak sulit untuk diajak bekerjasama dalam mmebuat motivasi kerja. Oleh sebab itu kebiasaan yang dibawanya sejak kecil, nilai yang 
dianut dan sikap bawaan seseorang sangat memotivasinya (Sayuti, 2006).

Usia berpengaruh terhadap kepatuhan seseorang dalam melakukan enam langkah cuci tangan dengan benar. Usia seseorangsecara garis besar menjadi indikator dalamsetiap mengambil keputusan yang mengacu pada setiap pengalamannya (Niven, 2002). Berdasarkan hasil penelitian diperoleh sebagian besar responden berusia 31-40tahun.Umur 31-40 tahun bagi peawat dianggap sebagai umur yang sudah matang, sehingga umur 31-40 tahun bagi perawat diharapkan dapat meningkatkan kepatuhannya, pengetahuan dan pengalaman yang dimilikinya untuk meningkatkan pelayanan kepada pasien (Saragih dan Rumapea, 2010).

Jenis kelamin

Berdasarkan hasil penelitian jenis kelamin perawat mayoritas adalah perempuan 40 responden $(58,8 \%)$. Hasil penelitian ini sesuai dengan penelitian oleh Asnan (2011), yang didapatkan hasil $75,4 \%$ perawat berjenis kelamin perempuan. Hal ini berdasarkan survey secara keseluruhan di Rumah Sakit Liun Kendage didominasi oleh perawat perempuan yang terbesar diseluruh ruangan rawat inap maupun rawat jalan.

Hal ini sesuai dengan pendapat Kozier \& Erb's (2005) tentang filosofi mother instinct bahwa mayoritas perawat datang dari kaum perempuan, dimana seorang perempuan memiliki naluri untuk merawat diri sendiri dan orang lain sebagaimana tercermin pada seorang itu serta naluri yang sederhana dalam memelihara kesehatan keluarganya.

\section{Pendidikan}

Berdasarkan dari 61 responden sebagian kesemuanya berpendidikan D3. Hal ini sesuai dengan Keputusan Menteri Kesehatan (Kepmenkes) Nomor 1239 tahun 201 yang menyatakan bahwa standar minimal pendidikan perawat pada institusi pelayanan kesehatan adalah Diploma Iii Keperawatan (Depkes RI, 2001). Sesuai yang dikemukakan oleh Soeroso (2003) bahwa lebih dari $60 \%$ perawat masih berpendidikan Diploma III di Indonesia.

Syadan (dalam Sayuti, 2006) menyatakan bahwa faktor-faktor yang mempengaruhi motivasi diantaranya adalah tingkat pendidikan seseorang. Sebagai seorang perawat yang memiliki tingkat pendidikan yang lebih tinggi, biasanya akan lebih termotivasi karena sudah memiliki wawasan yang lebih luas dibandingkan dengan perawat yang lebih rendah pendidikannya.

Hasil penelitian hubungan antara motivasi perawat rawat inap dengan tingkat kepatuhan dalam melakukan 6 langkah cuci tangan yang benar di RSI Klaten sebagian besar responden yang memiliki motivasi yang lemah dalam melakukan 6 langkah cuci tangan yang benar yaitu sebanyak 32 responden atau sebesar 52,5\%.

Hal ini membuktikan bahwa aspek cuci tangan sebelum melakukan tindakan diperhatikan oleh perawat. Sedangkan kegunaan cuci tangan menurut Tietjen (2004) untuk mencegah infeksi yang ditularkan melalui tangan dengan menyingkirkan kotoran dan debu serta menghambat atau membunuh mikroorganisme pada kulit.Hal ini sesuai dengan teori dari Garner dan Favero (1985) cit Majid (2000) yang merekomendasikan kepada perawat untuk selalu mencuci tangan sebelum dan sesudah melakukan perawatan. Teori ini juga sesuai dengan pendapat Depkes RI (2003), yang menyatakan cuci tangan harus selalu dilakukan dengan benar sebelum dan sesudah melakukan tindakan perawatan walaupun memakai sarung tangan atau alat pelindung lain untuk menghilangkan mikroorganisme yang ada ditangan sehingga penyebaran penyakit dapat dikurangi dan lingkungan terjaga dari infeksi.

Hal ini senada dengan penelitian Ahmad Mudayana (2010), yang berjudul pengaruh motivasi dan beban kerja terhadap kinerja karyawan di rumah sakit Nur Hidayah Bantul dengan hasil Ada pengaruh motivasi kerja terhadap kinerja karyawan di RS Nur Hidayah Bantul. Ada pengaruh faktor motivasi intrinsik dan motivasi ekstrinsik terhadap kinerja karyawan di RS Nur Hidayah Bantul. Ada pengaruh sub variabel motivasi intrinsik (tanggung jawab, pengakuan, prestasi kerja, pengembangan karir, pekerjaan, promosi) terhadap kinerja karyawan di RS Nur Hidayah Bantul. pengembangan karir memiliki pengaruh tertinggi dibandingkan dengan sub variabel motivasi intrinsik lainnya. Tidak ada pengaruh sub variabel motivasi ekstrinsik (hubungan kerja dan gaji) terhadap kinerja karyawan di RS Nur Hidayah Bantul. Ada pengaruh sub variabel kondisi kerja dalam motivasi ekstrinsik terhadap kinerja karyawan di RS Nur Hidayah Bantul. 
Kepatuhan perawat rawat inap dalam melakukan 6 langkah cuci tangan yang benar

Hasil penelitian hubungan antara motivasi perawat rawat inap dengan tingkat kepatuhan dalam melakukan 6 langkah cuci tangan yang benar di RSI Klaten sebagian besar responden yang memiliki kepatuhan tidak patuh dalam melakukan 6 langkah cuci tangan yang benar yaitu sebanyak 26 responden atau sebesar 42,6\%.

Menurut data Riset Kesehatan Dasar (RISKESDAS) tahun 2013, prevalensi nasional berperilaku benar dalam cuci tangan adalah $23,2 \%$. Kepatuhan adalah suatu kondisi yang tercipta dan terbentuk melalui proses dari serangkaian perilaku yang menunjukkan nilai nilai ketaatan, kepatuhan, kesetiaan, keteraturan dan ketertiban. Sikap atau perbuatan yang dilakukan bukan lagi atau sama sekali tidak dirasakan sebagai beban, bahkan sebaliknya akan membebani dirinya bila tidak dapat berbuat sebagaimana lazimnya (Prijadarminto,2003)

Kepatuhan perawat dalam melakukan cuci tangan enam langkah dalam penelitian ini sebagian besar adalah tidak patuh. Mayoritas perawat berperilaku negatif yang ditunjukkan dengan ketidak patuhan dalam melakukan 6 langkah cuci tangan untuk menghindari kejadian berbagai penyakit.

Menurut jurnal dari Roly Marwan, 2015 dengan judul hubungan umur, lama kerja, pendidikan, dan motivasi, dengan kepatuhan perawat melakukan 6 langkah 5 moment cuci tangan di ruang ICU RSUD Ulin Banjarmasin ada hubungan yang sangat kuat pada motivasi dengan kepatuhan perawat dalam melakukan 6 langkah lima moment cuci tangan.

Hubungan antara motivasi perawat rawat inap dengan tingkat kepatuhan dalam melakukan 6 langkah cuci tangan yang benar di RSI Klaten

Ada hubungan yang signifikan (bermakna) antara motivasi perawat rawat inap dengan tingkat kepatuhan dalam melakukan 6 langkah cuci tangan yang benar di RSI Klaten ( $p$ value $=0,000$ ).

Kepatuhan merupakan sikap seseorang untuk bersedia mentaati dan mengikuti spesifikasi, standar atau aturan yang telah diatur dengan jelas, dimana aturan tersebut diterbitkan oleh perusahaan yang bersangkutan dan lembaga lain yang berwenang (Saifuddin dalamWardani, 2009)
Hubungan motivasi perawat rawat inap dengan tingkat kepatuhan dalam melakukan 6 angkah cuci tangan yang benar di RSI Klaten diperkuat dengan hasil penelitian yang menunjukkan tabulasi silang yang sesuai dengan teori kepatuhan dan cuci tangan.Pada penelitian ini didapatkan bahwa sebagian besar responden memiliki motivasi yang lemah dalam melakukan 6 langkah cuci tangan yang benar, begitu juga sebagian besar responden memiliki kepatuhan dalam melakukan 6 langkah cuci tangan yang benar yaitu dengan kategori tidak patuh.

Hal ini senada dengan penelitian dengan judul Hubungan Motivasi dengan Kepatuhan Perawat dalam Praktik Hand Hygienedi Ruang Cendana IRNA RSUP Dr.Sardjito Yogyakarta (Quirina, dkk, 2015) didapatkan hasil Motivasi perawat sebagian besar baik yaitu 97,5\%, kepatuhan perawat sebagian besar dalam kategori baik sebesar 97,5\%, ada hubungan antara motivasi dengan kepatuhan perawat dalam praktik hand higiene di ruang Cendana IRNA I RSUP Dr Sardjito Yogykarta dengan nilai signifikansi $\mathrm{p}<0,05$ yaitu sebesar 0,000 dan nilai koefisiaensi sebasar 0,559 .

Motivasi merupakan proses prikologis yang dapat menjelaskan perilaku seseorang. Berdasarkan hasil penelitian melalui penyebaran kuesioner tentang motivasi perawat diketahui bahwa motivasi perawat dalam melakukan enam langkah cuci tangan dengan benar di ruang perawatan RSI Klaten adalah sedang sementara itu tingkat kepatuhan perawat adalah mayoritas tidak patuh dalam melakukan enam langkah cuci tangan dengan benar. Sementara itu untuk tabulasi silang antara motivasi perawat dengan tingkat kepatuhan dalam melakukan enam langkah cuci tangan dengan benar dikehatui bahwa motivasi perawat berhubungan dengan tingkat kepatuhan perawat dalam melakukan enam langkah cuci tangan dengan benar. Karena dengan motivasi yang tinggi yang dimiliki oleh perawat maka akan dapat meningkatkan kepatuhan perawat dalam melaksanakan enam langkah cuci tangan yang benar.

\section{SIMPULAN}

Berdasarkan dari hasil penelitian yang telah dilaksanakan maka simpulan yang dapat diambil adalah sebagai berikut :

1. Berdasarkan hasil penelitian diketahui bahwa dari 61 reponden yang dijadikan sampel 
bahwa mayoritas responden berumur antara 31-40 tahun dengan jenis kelamin terbanyak adalah perempuan dan tingkat pendidikan perawat mayoritas adalah D3 Keperawatan.

2. Motivasi perawat dalam cuci tangan enam 6 langkah cuci tangan yang benar di RSI Klaten sebagian besar responden adalah lemah sebanyak 32 responden $(52,5 \%)$

3. Tingkat kepatuhan perawat dalam melakukan cuci tangan enam 6 langkah cuci tangan yang benar di RSI Klaten sebagian besar tidak patuh yaitu 35 responden $(57,4 \%)$

4. Ada hubungan motivasi perawat rawat inap dengan tingkat kepatuhan dalam melakukan 6 langkah cuci tangan yang benar di RSI Klaten $(p$ value $=0,000)$

\section{REFERENSI}

Depkes RI. 2003. Pedoman Pengendalian Infeksi Nosokomial. Jakarta.

Hamzah B. Uno, 2008. Teori Motivasi dan Pengukurannya Analisis di Bidang Pendidikan, Bumi Aksara, Jakarta.

Kozier. B. 2007. Buku Ajar Perawatan Klinis. Edisi 5. Jakarta: ECG.

Mudayana, Ahmad Ahid. 2010. Pengaruh Motivasi Dan Beban Kerja Terhadap Kinerja Karyawan Di Rumah Sakit Nur Hidayah Bantul. Jurnal Universitas Ahmad Dahlan
Notoatmodjo, S. 2005. Metodologi Penelitian Kesehatan. Jakarta: Rineka Cipta.

Niven, N. 2002. Psikologi kesehatan pengantar untuk perawat dan professional kesehatan lain. Jakarta: EGC.

Nursalam. 2011. Konsep dan Penerapan Metodologi Penelitian Ilmu Keperawatan. Jakarta: Salemba Medika.

Potter \& Perry. 2005. Fundamental Keperawatan. Volume 1. Jakarta: EGC.

Rolly. 2015. Hubungan umur, lama kerja, pendidikan, dan motivasi dengan kepatuhan perawat melakukan enam langkah lima moment cuci tangan di ruang ICU RSUD Ulin Banjarmasin. Caring, Vol. 3, No.2, 49-58.

Saragih \& Rumpea. (2010). Hubungan Karakteristik Perawat denganTingkat Kepatuhan PerawatMelakukan Cuci Tangan di Rumah Sakit Columbia. Medan: Universitas Darma Agung

Sayuti. 2006. Motivasi Dan Faktor-Faktor Yang Mempengaruhi. Jakarta: Penerbit Ghalia Indonesia

Sugiyono. 2014. Metode Penelitian Kuantitatif, Kualitatif dan $R \& D$. Bandung : Alfabeta.

WHO. 2012. Indicator Pasien Safety. Modul Pencegahan Penyakit Infeksi Rumah Sakit. Rineka Cipta. Jakarta. 